\title{
Real Classes Vs Online Classes: A Comparative Study on the Chosen Course of HRM Students of Gulf University, Kingdom of Bahrain
}

\author{
https://doi.org/10.3991/ijet.v15i18.15267 \\ Muskan Nagi ${ }^{(凶)}$, Janaki Bojiah \\ Gulf University, Sanad, Bahrain \\ dr.muskan.nagiegulfuniversity.edu.bh
}

\begin{abstract}
The technologically sound students of today are open and very much inclined to adopt new modes of knowledge transfer inclusive of online classes. However, there are various viewpoints related to the aspect of online classes as not much of comparative studies on real classes and online classes have been carried out in Bahrain. Therefore, the need for a research study to find out the merits and demerits of real classes and online classes was identified. The objective of the study was to find out the reasons behind the preference of a class of HRM students of Gulf University, Kingdom of Bahrain with respect to the mode of its imparting - whether it is the real classes or online classes. A class of a HRM course was taken as a sample with the same faculty handling real classes before the midterm exam and online classes after midterm exam so that analysis could be carried out on the responses of the same set of students exposed to both the modes of teaching imparted by the same teacher. With an exhaustive literature review to trace the emergence of online classes and the impact of the same on the current generation, the study recorded the students' responses in the form of a survey questionnaire. The quantitative analysis was carried out using Statistical Package for Social Sciences (SPSS) and the variables were tested for the significance of the relationship using the Pearson Chi-Square test. The findings implicitly confirm that the students are comfortable with both real classes and online classes as far as the instructor is efficient to use appropriate pedagogies and digital tools to support learning.
\end{abstract}

Keywords - Real classes, online classes, Gulf University, HRM.

\section{$1 \quad$ Introduction}

Twenty-first century is an era of globalization, economic upheavals, and technological advancements. In the contemporary world, the evolving cybernation and changing environment have made it possible for every individual to afford the smart devices as these are no more considered as items of luxury or symbols of economic status. Initially the basic mobile phones were used only for calling and messaging. With the continuous intensity of Internet revolution, there isn't any dearth of highspeed connectivity anymore. With the increase in the number of communication 
network providers and the healthy competitive spirits that prevail in their minds, a range of Internet packages are available at affordable prices with special offers then and there. The mobile technology has shifted from being a basic mobile phone with press buttons to the smart devices with touchscreen. This enabled the mobile technology to extend to social media communication, audio-visual transfer, HD clarity photos, external memory storage etc. With Internet, the smart devices bring in the world to your home. Email, information, entertainment, varied function specific apps and so on are some of the mentionable items that are readily available to use. We name it and it has it - is ideal to be used for Internet only and the smart devices are the facilitators. This has become a part and parcel of the field of education also. In 2020, with the outbreak of Corona virus worldwide, every corner of the globe is forced to be shut down. To tackle the situation, the educators of every country decided to opt for online teaching. Gulf University, Kingdom of Bahrain also enforced online teaching on its community members which laid the platform for this study. We conceived the thought of trying to find out the preference of the students with respect to the mode of teaching.

\section{Literature Review}

Since ancient times, the purpose of education has always been to cultivate a sound mind in the sound body. However, there has been varied views in this regard as to how education should be and the kind of objectives it should aim to develop in students. Martin Luther King Jr. [1] says that the function of education is to "teach one to think intensively and to think critically. But education which stops with efficiency may prove the greatest menace to society. The most dangerous criminal may be the man gifted with reason but no morals. We must remember that intelligence is not enough. Intelligence plus character - that is the goal of true education." Whereas Aristotle [2] realizes that "education should be limited to what is appropriate for the pupil, taking account of his age, character, and so on." He adds that it should focus on both individual and social development that help a person attain selfrealization.

Further, John Dewey [3] defines, "the purpose of education has always been to everyone, in essence, the same to give the young the things they need in order to develop in an orderly, sequential way into members of society. Any education is, in its forms and methods, an outgrowth of the needs of the society in which it exists." These statements make it clear that education is not about getting academic degrees or competent jobs but about self-realization which he or she can achieve only by playing an active part in collaborative pursuits in the familial, social and professional fronts.

The conventional classes are the classes where the classmates work together to cultivate their intellectual and social skills. However, with the advancement of technology and the changing social atmosphere, the entry of online learning has become unavoidable as discovered by Hariadi et al. [4] and Suartama et al. [5]. The study conducted by Karabatzaki [6] confirmed that use of technology has enriched student engagement drastically. The availability of a range of affordable smart devices, high-speed internet, abundant e-resources and cost-effective internet 
packages have really played a significant role in shrinking the world into a global village. The students of today who are called as "digital natives" by Reich et al. [7] are technologically sound as Makwanya and Oni [8] pointed out that, "Individuals are now used to producing, writing, storing and retrieving documents electronically on a wide range of electronic devices."

Hence, the teachers become bound to be at pace with the changing academic culture and adopt e-resources effectively as proposed by Dayakar [9] thus, "The relevance for teaching is not exhaustive but a teacher's ability will determine how efficiently the e-resources can be exploited enhance teaching." "Using more multimedia in their presentations and incorporating digital resources such as academic games and interactive websites into lesson plans," have become mandatory for the teachers globally, according to Engbrecht [10]. The growing popularity and familiarity of e-books confirm the idea of e-books by Boticki et al. [11] thus, "Ebooks have become a popular medium for content delivery and are being widely accepted." On the contrary, the findings of Abuloum et al. [12] suggested that there is a continuance in students' preference for print books.

Nevertheless, Schutte [13] felt that the real classes could create an ambience that could pressurize students owing to its intimidating structure that is limited within four closed walls. In contrast, the online classes lay the platform for the students to express their views openly and confidently. As quoted in Moore [14], online class is the "one that allows learners to perceive the environment, assess situations and performance, perform actions and proceed through experiences and lessons that will allow them to perform better with more experience on repetition on the same tasks in similar circumstances." To add to this, Siegel and Sousa [15] mentioned that the objective of online classes is to equip learners with critical skills like analyzing and synthesizing ideas from various sources by making inferences and identifying the differentiation between actuals and viewpoints keeping in mind the perspectives of others. This encapsulates that online classes are not lagging behind in catering to the demands of academic purposes which have been achieved since ages only through real classes.

Now-a-days, there are many advanced digital tools available in the market to execute online classes and MS Teams is of the competent ones. It is a collaborative medium that permits everyone in the team to interact, work with each other, share and express their ideas and thoughts with a high level of self-regulation as proposed by Rollett et al. [16]. Baig [17] found out that the students perform better when the lessons are imparted via online classes as they are exposed to varied learner-centric study materials available for the students, communicate to the teacher in oral or written form, submit the documents for feedback etc. round the clock. As confirmed by Purnomo et al. [18], online classes develop more independent learning as the students learn at their own pace. According to Merzifonluoglu [19], the smart tools bring in vivid learning experience and the findings of Okert [20] and Leonard \& Snyman [21] confirmed that the technology has a positive impact on the learners. Contrary to this, Johnston \& Ferguson [22] asserted that most of the learners hardly attempt to explore smart tools like annotation, highlighting etc. Additionally, the studies of Banik et al. [23], Johnston \& Salaz [24] as well as Piramanayagam \& Seal [25] brought out the fact that the students prefer print materials for the ease of highlighting and Mizrachi [26] seconded this opinion and acknowledged that the students' preference was to print out the e-resources for the purpose of highlighting 
and note-taking. Despite all odds, online classroom provides a platform to explore web resources by using links, access live applications, experience hands-on practice with software applications, respond to multiple-choice survey questionnaires, compile notes with annotation tools, highlight using interactive tools, record class discussions, play games and watch video lessons. Additionally, collaborative learning is enhanced through online chat and group discussions. The findings of Adeyinka et al. [27] and Wang [28] discovered that there has been an increase in the intensity of using online resources for academic purposes.

\section{$3 \quad$ Research Methodology}

\subsection{Research design}

This section deals with the research design adopted for the purpose of the study. It includes the sample design as well as the tools and techniques that were applied to measure variables and their relationships. The study was conducted by a self-designed questionnaire. The questionnaire was divided into five sections. Section A: Demographic profile, Section B: Awareness of real classes and online classes, Section C: Aspects of real classes, Section D: Aspects of online classes and lastly Section EFactors affecting online classes. Questionnaire was based on a 5-point Likert scale, where respondents ranked their level of agreement with 5 representing parameters namely 5 strongly agree, 4 agree, 3 neutral, 2 disagree and 1 strongly disagree. The data were collected from a class of prospective HRM graduates of Gulf University, Bahrain. For collecting data, convenience sampling technique was used. There was a total of 45 respondents and all responses were considered for the study. The reliability statics of 35 items shows the value of Cronbach Alpha to be 0.985 , which is highly significant that acknowledges all the items to be reliable.

Table 1. Summary of Sample Structure

\begin{tabular}{|c|c|c|}
\hline$(\mathrm{N}=45)$ & Number of Respondents & $\begin{array}{c}\text { Percentage } \\
\text { (Approximately) }\end{array}$ \\
\hline \multicolumn{3}{|c|}{ GENDER } \\
\hline Male & 11 & $24.4 \%$ \\
\hline Female & 34 & $75.6 \%$ \\
\hline \multicolumn{3}{|l|}{ MARITAL STATUS } \\
\hline Single & 34 & $75.6 \%$ \\
\hline Married & 11 & $24.4 \%$ \\
\hline \multicolumn{3}{|c|}{ AGE GROUP } \\
\hline Less than 25 years & 30 & $66.7 \%$ \\
\hline 25-30 years & 10 & $22.2 \%$ \\
\hline 30 and Above & 5 & $11.1 \%$ \\
\hline \multicolumn{3}{|c|}{ Experience } \\
\hline Less than 2 year & 32 & $71.1 \%$ \\
\hline 2-5 year & 8 & $17.8 \%$ \\
\hline Above 5 year & 5 & $11.1 \%$ \\
\hline
\end{tabular}




\subsection{Data analysis}

Statistical Package for Social Sciences (SPSS) was used for data analysis. Variables were tested for the significance of the relationship using the Pearson ChiSquare test. Further, factor analysis was also used to understand which factor is considered as the most important factor for online classes.

\section{Findings.}

Pearson's Chi-Square test was applied to determine students' perceptions towards real classes vs online classes and to understand the significant of relationship of awareness, aspects of real classes, aspects of online classes and factors affecting online classes with different demographic profile of variables.

Table 2. Summary of Pearson's Chi-Square Test

\begin{tabular}{|l|c|c|l|}
\hline \multicolumn{1}{|c|}{ Variable } & Value & P Value & \multicolumn{1}{c|}{ Significance level } \\
\hline Gender* Awareness & .154 & .133 & Not significant \\
\hline Gender* Real Classes & 7.329 & .007 & Significant \\
\hline Gender*Online Classes & .490 & .543 & Not significant \\
\hline Gender* FAOC & 1.010 & .360 & Not significant \\
\hline Marital * Awareness & 192.698 & .000 & Significant \\
\hline Marital* Real Classes & 151.638 & .000 & Significant \\
\hline Marital*Online Classes & 88.418 & .000 & Significant \\
\hline Marital*FAOC & 83.277 & .000 & Significant \\
\hline Age* Awareness & 284.879 & .000 & Significant \\
\hline Age* Real Classes & 184.307 & .000 & Significant \\
\hline Age*Online Classes & 226.664 & .000 & Significant \\
\hline Age*FAOC & 103.826 & .000 & Significant \\
\hline Exp* Awareness & 184.452 & .000 & Significant \\
\hline Exp* Real Classes & 154.197 & .000 & Significant \\
\hline Exp* Online Classes & 66.889 & .000 & Significant \\
\hline Exp*FAOC & 129.815 & .000 & Significant \\
\hline
\end{tabular}

Further, while applying factor analysis, a KMO value greater than 0.5 is desirable. For the factor analysis to be appropriate, the variables must be correlated. Small values of KMO statistics indicate that the correlations between pairs of variables cannot be explained by other variables and that factor analysis may not be appropriate. Table 3 shows the component matrix of factors affecting online classes thus: 
Table 3. Component Matrixa1

\begin{tabular}{|l|c|}
\hline \multirow{2}{*}{} & Component \\
\cline { 2 - 2 } & 1 \\
\hline FAOC5 & .956 \\
\hline FAOC3 & .948 \\
\hline FAOC2 & .925 \\
\hline FAOC4 & .906 \\
\hline FAOC1 & .904 \\
\hline
\end{tabular}

Extraction Method: Principal Component Analysis

a1 components extracted

\section{Discussion}

From Section B1 and B2 of awareness of real classes and online classes, $52.3 \%$ (strongly agreed) of respondents were fully aware of the digital tools and online classes and as per findings there wasn't any student who was not aware of the usage of email and internet browsing. And the result of Chi Square test indicates that there is no significant relationship among gender of respondents and awareness of respondents. This means no matter whether the respondent is male or female it has no impact on awareness related to technology and online classes. Whereas awareness has high significant relationship with age, marital status and experience of respondents. This encapsulates the idea that the awareness is directly proportional to age, experience and maturity level.

\subsection{Section C: Aspects of real classes}

Among the respondents, $54 \%$ of respondents believe that real classes are more practical and livelier. The result of Chi Square test means that real classes have highly significant relationship with gender, age, marital status and experience of respondents. This is because student's perception for real classes is based on demographic profile of a respondent. The more is the age, experience and maturity, the more is the understanding of real classes.

\subsection{Section D: Aspects of online classes}

For online classes, respondents show a very positive and highly significant result. Around $37.8 \%$ of respondents believe that they don't mind if they never actually meet their instructor or classmates in person whereas $33 \%$ of respondents also believe that online classes can be conducted at any place without wasting time and high-quality learning can take place without face-to-face interaction. In addition, the results of ChiSquare test indicate a significant association of gender, age, marital status and experience of respondents with online classes. This can be interpreted culturally that early marriages and increased responsibilities corner the females of the country to 
give more preference to online classes so that they can pursue their higher studies and maintain the household simultaneously.

\subsection{Section D: Factors affecting online classes}

As per the study, the five factors viz even flow of speedy Internet, calm environment, regular participation, efficiency of the smart devices, and instructor support are considered as significantly responsible aspects of online classes. Among these five, only one factor has turned out to be the most important factor that is FAOC5: "Instructor support" for the smooth functioning of online classes. This result has turned out to be very useful and important that without the support of the instructor no matter whether the classes are real or online, learning cannot be successful.

\section{Conclusion}

The findings make it clear that the students are contented with both real classes and online classes as far as the instructor possess the capability to identify and use the right pedagogies, informative resources and competent digital tools effectively. The responses have by and large helped to list the advantages and disadvantages of real classes and online classes; however, it is important to note that the mode of teaching is topic specific. Whether online classes help students enhance social development is still unanswered as building skills like team building, leadership, body language etc. are practically difficult to be imparted through online classes. In addition, measuring competencies of students related to autonomy, context and responsibility will remain a challenge too. Moreover, the instructor is stressed most of the online class duration in terms of monitoring and controlling of student engagement. This study is limited to a class of students and an instructor whereas it can be furthered by extending to all the courses pertaining to the programme. Comparative studies can be initiated involving two or more instructors. Longitudinal research can be conducted as to whether the university should completely switch to online classes. Comparing online classes of the country with other countries can further help the educationists to find out the students' preference in this regard.

\section{$7 \quad$ References}

[1] Carson, C., Luker, R., \& Russell, P. A. (Ed.). (1992). The Papers of Martin Luther King, Jr. Volume I: Called to Serve, January 1929-June 1951. University of California Press at Berkeley and Los Angeles. https://kinginstitute.stanford.edu/king-papers/documents/pur pose-education. https://doi.org/10.1017/s0021875800031431

[2] Hummel, C. (1993). Aristotle (384-322 B.C.). Prospects: the quarterly review of comparative education, 23(1-2), 39-51. https://unesdoc.unesco.org/ark:/48223/pf0000084 $\underline{263}$ 
[3] Dewey, J. (1934). Individual Psychology and Education. The Philosopher, 12. https:// edschucated.wordpress.com/2017/03/08/immooc-1-the-purpose-of-education/

[4] Hariadi, B., Sunarto, M. J. D., Sudarmaningtyas, P., \& Jatmiko, B. (2019). Hybrid learning by using brilian applications as one of the learning alternatives to improve learning outcomes in college. International Journal of Emerging Technology in Learning, 14(10), 34-45. https://doi.org/ 10.3991/ijet.v14i10.10150

[5] Suartama, I. K., Setyosari, P. Sulthoni, \& Ulfa, S. (2019). Development of an instructional design model for mobile blended learning in higher education. International Journal of Emerging Technologies in Learning, 14(16), 4-22. https://doi.org/10.3991/ijet.v14i16. 106 $\underline{33}$

[6] Karabatzaki, Z., Stathopoulou, A., Kokkalia, G., Dimitriou, E., Loukeri, P., Economou, A. \& Drigas, A. (2018). Mobile application tools for students in secondary education: An evaluation study. International Journal of Interactive Mobile Technologies, 12(2), 142-161. https://doi.org/10.3991/ijim.v12i2.8158.

[7] Reich, S. M., Yau, J.C., Xu, Y., Muskat, T., Uvalle, J., \& Cannata, D. (2019). Digital or Print? A comparison of preschoolers' comprehension, vocabulary, and engagement from a print book and an e-book, 5(3), 1-16. https://doi.org/10.1177/2332858419878389

[8] Makwanya, C., \& Oni, O. (2019). E-books preference compared to print books based on student perceptions: A case on University of Fort Hare students. International Journal of Interactive Mobile Technologies, 13(12), 236-245. https://doi.org/10.3991/ijim.v13i12.108 $\underline{40}$

[9] Dayakar, G. (2018). Use of e-resources in higher education: Advantages and concerns. Journal of Applied and Advanced Research, 3(1), S17-S19. Phoenix Research Publishers. https://doi.org/10.21839/jaar.2018.v3is1.160

[10] Engbrecht, J. R. (2018). Digital textbooks versus print textbooks. Culminating Projects in Teacher Development. 35. https://repository.stcloudstate.edu/ed_etds/35.

[11] Boticki, I., Akçapınar, G., \& Ogata. H. (2019). E-book user modelling through learning analytics: The case of learner engagement and reading styles. Interactive Learning Environments, 27(5-6), 754-765. https://doi.org/10.1080/10494820.2019.1610459.

[12] Abuloum, A., Farah. A., Kaskaloglu, E., \& Yaakub, A. (2019). College students' usage of and preferences for print and electronic textbooks. International Journal of Emerging Technologies in Learning, 14(7), 80-97. https://doi.org/10.3991/ijet.v14i07.9871

[13] Schutte, J. G., (1996). Virtual Teaching in Higher Education: The New Intellectual Superhighway or Just Another Traffic Jam? http://www.csun.edu/ egodard/dta/docs/PVirtualTeaching.pdf

[14] Moore, J. C. (2002). Elements of Quality: The Sloan-C Tm Framework. Sloane Centre of Online Education. USA.

[15] Siegal, M. A., \& Sousa, G. A. (1994). Inventing the Virtual Textbook: Changing the Nature of Schooling, 1-9. https://www.researchgate.net/publication/234664696_Inventing the_Virtual_Textbook_Changing the_Nature_of_Schooling

[16] Rollett, H., Lux, M., Strohmaier, M., Dosinger, G. \& Tochtermaann, K. (2007). The web 2.0 way of learning with technologies. International Journal of Learning Technology, 3(1), 87-107. https://doi.org/10.1504/ijlt.2007.012368

[17] Baig, M. A., (2011). A critical study of effectiveness of online learning on students' achievement. i-manager's Journal of Educational Technology, 7(4), 28-34.

[18] Purnomo, A., Kurniawan, B., \& Aristin, N. (2019). Motivation to Learn Independently through blended learning. International Conference on Educational Research and Innovation (ICERI 2018). https://doi.org/10.2991/iceri-18.2019.55 
[19] Merzifonluoglu, A. \& Gonulal, A. (2018). Review of digital language learning and teaching: Research, theory and practice. Language Learning \& Technology, 22(1), 65-68.

[20] Oxkert, D. (2018). Using a tablet computer for EFL positive self-review: Increase in selfdetermination theory-based learning motives. Calido Journal, 35(2), 1-18. https://doi. org $/ 10.1558 /$ cj.32185

[21] Leonard, A., \& Snyman, M. (2019). E-books: yes or no? A case study of undergraduate students at the University of Namibia. Emerald Publishing Limited, 38(3), 78-88. https:// doi.org/10.1108/cc-08-2018-0018

[22] Johnston, N. \& Ferguson, N. (2020). University students' engagement with textbooks in print and e-book formats. Technical Services Quarterly, 37(1), 24-43. https://doi.org/10.10 80/07317131.2019.1691760.

[23] Banik, P., Haque, M.A., Sultana, P., \& Kobir, M. R. (2019). E-book culture at Rajshahi University students in Bangladesh. International and Public Affairs, 3(2), 52-57. DOI: 10.11648/j.ipa.20190302.13.

[24] Johnston, N., \& Salaz, A. M. (2019). Exploring the reasons why university students prefer print over digital texts: An Australian perspective. Journal of the Australian Library and Information Association, 68(2), 126-145. https://doi.org/10.1080/24750158.2019.158785 $\underline{8}$.

[25] Piramanayagam, S., \& Seal, P.P. (2020). The choice between e-books and printed books: A study among hospitality and tourism educators and learners. ProQuest.

[26] Mizrachi, D., Salaz, A. M., Kurbanoglu, S., \& Boustany, J. (2018). Academic reading format preferences and behaviors among university students worldwide: A comparative survey analysis. PloS One, 13(5), e0197444. https://doi.org/10.1371/journal.pone.0197444.

[27] Adeyinka, T., Dare, O., Adebisi, O., \& Lawal, A. (2018). Perception and usage pattern of e-books among library and information science students in selected universities in Nigeria. Journal of Library and Information Technology, 38(2), 132-140. https://doi.org/10.14429/ djlit.38.2.11111

[28] Wang, J. (2018). Retrieving critical design factor of ebook for older people in Taiwan. Telematics and Informatics, 35(7), 2016-2027. https://doi.org/10.1016/j.tele.2018.07.005

\section{Authors}

Dr. Muskan Nagi works in the Department of Administrative Sciences as Assistant Professor at Gulf University in Bahrain. dr.muskan.nagi@gulfuniver sity.edu.bh

Dr. Janaki Bojiah works for Gulf University of Bahrain as Asst Prof in the Department of General Sciences. dr.janaki.bojiah@gulfuniversity.edu.bh

Article submitted 2020-04-28. Resubmitted 2020-05-28. Final acceptance 2020-06-04. Final version published as submitted by the authors. 